\title{
Acadiensis
}

Journal of the History of the Atlantic Region

Revue d'histoire de la région Atlantique

\section{Rethinking Access to the Past: History and Archives in the Digital Age}

\section{Thomas Peace et Gillian Allen}

Volume 48, numéro 2, automne 2019

URI : https://id.erudit.org/iderudit/1067775ar

Aller au sommaire du numéro

Éditeur(s)

Department of History at the University of New Brunswick

ISSN

0044-5851 (imprimé)

1712-7432 (numérique)

Découvrir la revue

Citer cet article

Peace, T. \& Allen, G. (2019). Rethinking Access to the Past: History and Archives in the Digital Age. Acadiensis, 48(2), 217-229. d'utilisation que vous pouvez consulter en ligne. 


\section{Rethinking Access to the Past: History and Archives in the Digital Age}

SOME HISTORICAL QUESTIONS ARE EASIER ANSWERED than others. Much of what determines the degree of difficulty with which a specific question can be answered is the access a historian has to their evidence. A simple query about the past might be answered within minutes by querying Wikipedia; a more complex question on a local topic might require a short visit to a nearby archival collection, library, or museum or even multiple archives. As the questions we ask of the past increase in sophistication, historians require greater investments of both time and money.

The nature of these archives can also compound the challenges historians face. The quality of the documentary record as well as its structure, curation, and language all pose obstacles lengthening the research process and adding to its costs. Except for highly specific and local questions, the answer to most historical inquiries requires the use of institutional archives and collections. For the most part, the practice of historical interpretation done well is slow, costly, and often quite complicated.

Additionally, the work of history involves at least two intertwined ways of relating to the past. One way that people approach the past is through local and lived experience. This approach often underpins family and community histories; genealogy and history societies, local libraries, and museums support it. Researchers whose interest in the past is shaped by their local realities may periodically extend their historical inquiry beyond these institutions, but they often remain restricted by financial, vocational, or family commitments. The other approach is the one most often (though not always) taken by professional historians. With institutional support from a university, museum, library, or government agency, historians working from this perspective often have access to considerably more financial, technological, and infrastructural resources as well as a broader professional network to support their work.

Archivists, librarians, curators, and historians have long been working against the challenges of access to archival materials. Though Early Canadiana Online (formerly CIHM) and the Champlain Society are probably the bestknown organizations for this type of work, the Atlantic region also has a 
rich late-19th- and early-2oth-century history of archival activism. In Nova Scotia, men like provincial archivist Thomas Atkins and Dalhousie English professor Archibald Macmechan published collections of documents related to the province's early colonial history. ${ }^{1}$ In New Brunswick, it was men like botanist William Francis Ganong and medical doctor John Clarence Webster who published volumes of early documents related to that province's history. ${ }^{2}$ As far as we know, Prince Edward Island did not have a similar champion of the archive but similar types of publications were also produced. ${ }^{3}$ These Atlantic efforts were matched by similar endeavours led by prominent Maine businessman and politician James Phinney Baxter, Canada's first national archivist Sir Arthur Doughty, New York medical doctor and archivist Edmund O'Callaghan, and Wisconsin librarian and lawyer Rueben Gold Thwaites. ${ }^{4}$ Taken together, all of these works weighted down library shelves during the late 19th and 2oth centuries as archival collections were made accessible through historical transcription in works that continue today to be foundational for the early study of the Atlantic region.

These archival anthologies are not without problems. Though they made historical records accessible to researchers unable to visit the archives, they also removed each document's text from its broader context. In some cases these editors translated documents without including the text in the original language (this is particularly the case for documents written in Indigenous languages). In other cases the documents were reordered or reorganized to make thematic sense to a reader rather than respecting their archival structure. In these collections, the archival context of the document - which itself was similarly curated - is often silenced in favour of a document itself.

1 Archibald M. MacMechan, ed., A Calendar of Two Letter-Books and One Commission-Book in the Possession of the Government of Nova Scotia, 1713-1741 (Halifax: Public Archives of Nova Scotia, 1900); Thomas Atkins, ed., Original Minutes of His Majesty's Council at Annapolis Royal, 1720-1739 (Halifax: Public Archives of Nova Scotia, 1908).

2 Nicholas Denys, The Description and Natural History of the Coasts of North America, ed. William F. Ganong (Toronto: Champlain Society, 1908); Dièreville, Relation of the Voyage to Port Royal in Acadia and New France, ed. John Clarence Webster and trans. Mrs. Clarence Webster (Toronto: Champlain Society, 1933).

3 See, for example, Public Documents on Various Subjects Connected with the Interests of Prince Edward Island (Charlottetown: Cooper and Bremner, 1841).

4 For examples of their edited documentary collections, see James Phinney Baxter, ed., Documentary History of the State of Maine (Portland: Maine Historical Society, 1869-); James Phinney Baxter, The Pioneers of New France in New England, with Contemporary Letters and Documents (Albany, NY: J. Munsell and Sons, 1894); Arthur G. Doughty and Adam Shortt, eds., Documents Relating to the Constitutional History of Canada, 1759-1791, Vol. 1 (Ottawa: J. Taché, 1918); and John Romeyn Brodhead, Documents Relative to the Colonial History of the State of New York: Procured in Holland, England, and France, ed. F.B. O'Callaghan (Albany, NY: Weed, Parsons, 1853-1887). 
Further, in nearly every case, these collections were organized to support a specific perspective on the past, be it regarding the Acadian deportation and early years of Nova Scotia for Atkins, travel narratives for Ganong, religious records for Thwaites (among other subjects related to American colonial expansion in the west), and state-building for the others. Today, we can see these documentary collections as emblematic of the interests of white, upperto-middle class men, who envisioned their historical work within a specific politics of nation-building.

Though somewhat subsiding by the mid-2oth century, the subsequent age of computing, and specifically the rise of the internet during the 1990s, has brought a return to this type of activity. Expanding dramatically in the late 1990 s and early 200os, digitized archival collections and finding aids have made archives more accessible to the public than at any time before. As a consequence, we have witnessed a dramatic return of the anthologization of the archive; in many ways, though the specific content has changed, digital archives have mirrored the approach of this earlier generation.

We can see this in the online presence of provincial and university archives in the region. In Nova Scotia, the provincial archives' virtual collections curate their collections related to Acadie, Mi'kma'ki, African, and Gaelic Nova Scotia; tourism and industry; and prominent individuals and communities in these and other categories. At 30 terabytes, or 1.3 million (of about 60 million) records, this is an impressive and important collection for which the archives should be recognized and commended for making their collections accessible

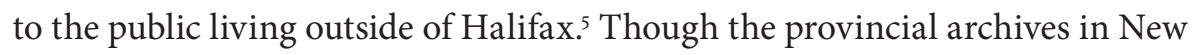
Brunswick and Prince Edward Island are less developed online, other cultural institutions, like universities and museums, have created similar resources. The University of New Brunswick's archives, for example, contains several online collections, such as the Loyalist Collection - an online resource that is complemented by other online collections at the university - and all of which help researchers to better navigate these documents. Similarly, Cape Breton University's Beaton Institute has curated several digital collections related to the island's Mi'kmaw and Gaelic cultures. Throughout the region there is an increased access to digital archives that greatly helps to reduce the challenges people interested in historical research face in conducting our work.

5 Special thanks to Paul Maxner, Senior Archivist Online Resources, Nova Scotia Archives, for sharing this information with us. 
Much like the earlier drive to make archives more accessible, the drive towards digitization is not without its problems. In his work on the turn towards digitized historical newspapers, for example, University of Waterloo historian Ian Milligan effectively demonstrates that online source material quickly became historians' focus of attention rather than print sources, which may have been more revealing. By looking at dissertations classified as "Canadian History," Milligan observed that the diversity of newspapers historians drew upon for their analysis atrophied to just the Toronto Star and Globe and Mail after those two papers digitized their collections and made them keyword searchable. ${ }^{6}$ Similarly, in her reflection in the American Historical Review on the problems and prospects of digitized archives, Lara Putnam emphasizes the importance of visiting archives and communities as part of the historical research process. Research as a methodical process is somewhat jettisoned when we draw on digital archives that point us to individual documents abstracted once again from their archival context.?

However, for personal, professional, and financial reasons, not all scholars and researchers can visit physical repositories. Where pertinent materials are scattered across broad areas or even continents, it can be financially impossible for some researchers to visit and conduct research in all archives or museums or libraries with holdings related to their studies. Does the study of history risk becoming elitist (or narrowed) if, in an age where materials can be safely digitized, the holders of materials are unable or simply decline to make those holdings available to a wider audience?

In many ways, with the digital turn in archival management we have replicated both the strengths and weaknesses of the late-19th century age of transcription. Though digital collections are often substantially different in scope, sometimes do a better job at providing context, and make archival collections even more accessible than their printed forbearers, their nature remains similarly limited in that they often bind research decisions by ease of access to documents rather than the quality of the documents themselves. Further, unlike the archival activists of the 19th century, whose name emblazoned the volumes they produced, in the digital age we seldom know who is behind the decisions made to digitize some archival materials over

6 Ian Milligan, "Illusionary Order: Online databases, Optical Character Recognition, and Canadian History, 1997-2010," Canadian Historical Review 94, no. 4 (December 2013): 540-69.

7 Lara Putnam, "The Transnational and the Text-Searchable: Digitized Sources and the Shadows They Cast," American Historical Review 121, no. 2 (April 2016): 377-402. 
others. Much like the archive itself, we are often left asking who exactly has made these selections that determine what is, and what is not, important for the public to have easier access? These are, of course, common questions in archive management, but, as we think about making archival documents public, ought not the criteria and process for selection be similarly transparent?

In our line of work, Mi'kmaw history, this asymmetry of access has long been a problem even as some of the documentary history related to the Mi'kmaq has become more accessible online. Because the present-day provinces of New Brunswick, Newfoundland, Nova Scotia, Prince Edward Island, Quebec, and the State of Maine have been superimposed upon Mi'kma'ki, understanding Mi'kmaw history requires deep engagement with archives throughout the northeast. In addition to local museums, archives, and universities, which often hold important resources, historians interested in understanding Mi'kmaw history from a broad perspective are required to visit museums, universities, and state-run and private archives in each of these jurisdictions as well as imperial/colonial centres such as Massachusetts, Ottawa, London, Paris, and Rome. Some of these institutions, like the Nova Scotia Archives, have considerable material available online, but many do not.

Mi'kmaw history is not unique in this regard. As a region comprised mostly of immigrants, and defined somewhat by migration, these challenges confront almost all historians working in the region. Chris Hodson's work in Acadian Diaspora, for example, draws on archives in Nova Scotia, New Brunswick, Massachusetts, Ontario, Pennsylvania, Michigan, and France. Likewise, Amani Whitfield's Blacks on the Border is similarly broad in that it draws on collections in Nova Scotia, Massachusetts, Quebec, Vermont, and Florida. ${ }^{8}$ Even if we look towards more recent histories, such as Burns, Clifford, and Peace's work on shipping and shipbuilding in late-19th-century Maitland, Nova Scotia, the international scope of the region is clear. The so-called "golden age of sail" cannot be understood without framing within histories of global trade and the 19th-century expansion of empire. ${ }^{9}$

8 Christopher Hodson, The Acadian Diaspora: An Eighteenth-Century History (New York: Oxford University Press, 2012); Harvey Amani Whitfield, Blacks on the Border: The Black Refugees in British North America, 1815-1900 (Burlington: University of Vermont Press, 2006).

9 See Judy Burns, Jim Clifford, and Thomas Peace, "Maitland's Moment: Turning Nova Scotia's Forests into Ships for the Global Commodity Trade in the Mid-Nineteenth Century," in Moving Natures: Mobility and the Environment in Canadian History, ed. Ben Bradley, Jay Young, and Colin M. Coates, https://prism.ucalgary.ca/bitstream/handle/1880/51203/Moving_natures_2016_ chapter01. pdf; jsessionid=58DEEOAAOF56BD1F5A0A04EDAF281577? sequence $=4$. 
For almost all historical research, unless a project is defined by a specific archival or documentary relationship, it is difficult to ask broad historical questions without consulting multiple archival collections. This may mean consulting the materials necessary to make detailed and nuanced historical interpretations difficult if not impossible, even for historians working within well-financed institutional structures. ${ }^{10}$ To do historical research well, historians are required to spend long periods in situ at archives (often away from family and the work place), making this type of academic work unrealistic for many. This is especially the case for historians working on their community's history, independent from the supportive resources to which professional historians have access.

In the northeast, there are a handful of archival or collections-based projects that have worked against these limitations. Though they share some similarity with the archival anthologies of the past, their collaborative structure points paths forward for digital archival practice. The Native Northeast Portal (formerly the Yale Indian Papers Project), for example, was created to overcome several of the obstacles outlined earlier in this essay. Aimed at counteracting the lack of access to, and cost to access, important archival collections, the project brings together diverse collections of primary sources by, or related to, First Peoples held in institutions throughout the northeastern United States. The Native Northeast Portal essentially reorganizes and combines archival collections around Indigenous polities and ideas, while maintaining reference to the original archival organization in which the document is physically held. The Great Lakes Research Alliance for Aboriginal Arts and Culture (GRASAC) is a similar project that directs its attention to using the online environment to digitally steward materials created by Indigenous artists and intellectuals but held in colonial institutional repositories. Both projects have been developed collaboratively between knowledge-keepers working in colonial and Indigenousmanaged institutions and governments; they are governed through structures that respect and involve the people whose heritage they seek to recover. To put it another way, they help reconcile the cleavage between many historians working at a local level and those working in more professional environments.

By reorganizing archival documents and collections in ways that are meaningful to First Peoples past and present, the Native Northeast Portal, in particular, overcomes some of the limitations found in other efforts to

10 The "well-financed institution" is, of course, a mythical beast. 
democratize the archives. Unlike the 19th-century documentary transcriptions with which we began, the Native Northeast Portal approach is collaborative, involving the nations whose written heritage is being digitized; eight Indigenous nations in Massachusetts assisted in the review of digital heritage items related to their nations and communities. It reaches across institutions to collect materials in one place. The project also hosts the New England Indian Papers Series Electronic Archive, which describes itself as

a scholarly critical edition of New England Native American primary source materials gathered presently from the partner institutions into one robust virtual collection, where the items are digitized, transcribed, annotated, and edited to the highest academic standards and then made freely available over the Internet, using open-source software. By providing annotated transcriptions, the Project's editors provide the Series users with useful information within a well-researched and balanced context necessary to understand the complexities of the historical record. ${ }^{11}$

Unlike institutional digital archives, which respect the institutional provenience of the archive, or the 19th-century critical editions with which we began, which abstract documents from their archival - and often documentary - origins, the portal brings together related documents that have been separated either as an inherent function of the purpose they sought to serve (i.e., correspondence) or by collecting practices that cared little for maintaining a collection's integrity, without rupturing these other contextual relationships. The project works, in other words, against the decisions archivists have made in the past, which tended to rupture these historical connections. The Native Northeast Portal serves as a model for what digital archives might promise for the future.

Over the past two years, we have been working to develop something similar to the Native Northeast Portal and GRASAC. Like the recently inaugurated Wabanaki Collection, hosted by the Mi'kmaq-Wolastoqey Centre at the University of New Brunswick (www.wabanakicollection.com), the Mi'kmaw Sovereignty Database (http://mikmawsovereignty.ca) is a prototype website that we hope will one day house a fairly comprehensive record of Mi'kmaw

11 "About the Yale Indian Papers Project," in Op-Ed: The Blog of the Yale Indian Papers Project, https://campuspress.yale.edu/yipp/about_yipp/. 
articulations of sovereignty. Using the Mukurtu platform, ${ }^{12}$ to which both the NNP and GRASAC have also turned, the Sovereignty Database (a working title only) aspires to bring together materials from a number of repositories to populate an online database consolidating references to Mi'kmaw territorial sovereignty, expressions of self-government and self-determination, and Mi'kmaq continued presence on, and use of, Mi'kma'ki. These examples could include, but are not necessarily limited to, written declarations, treaties, and knowledge held by Elders or within objects. In this early stage, we envision a user-generated database whereby users upload and edit this content under editorial oversight from a Mi'kmaw governance structure. This project remains very much a work in progress.

The best known example of continuing Mi'kmaw knowledge and articulation of their sovereignty and self-determination is the trial of Kji'saqmaw (Grand Chief) Gabriel Sylliboy on charges of violating provincial game laws in 1928. Kji'saqmaw Sylliboy's defence was that he had a treaty right to engage in harvesting. Well documented by William C. Wicken, ${ }^{13}$ Sylliboy's defence - unsuccessful in 1928, but ultimately successful when the previous court decision was overturned in 1985 - demonstrates that while the Crown and non-Mi'kmaw may have forgotten the treaties and forgotten that the Mi'kmaq continued to self-govern, the Mi'kmaq continue to see themselves as a self-determined nation.

It is this rich history that the database seeks to reveal. As one of the People of the Dawn, the Mi'kmaq were one of the first Indigenous peoples in what is now North America to have contact with Europeans and they were one of the first to have Europeans settle on their lands. The Mi'kmaq continued to believe in (and assert) their sovereignty, and this is manifested in the written record - throughout 500 years of contact and non-Mi'kmaq incursion and settlement albeit sometimes in ways that non-Mi'kmaw would not recognize as assertions of sovereignty and a right to self-determination. If we look at places like Lekil (Lequille) or Kjipuktuk (Tufts Cove) in Nova Scotia, for example, where historians Thomas Peace and Jacob Remes have called our attention to

12 Mukurtu defines its mandate as "a grassroots project aiming to empower communities to manage, share, narrate, and exchange their digital heritage in culturally relevant and ethicallyminded ways. We are committed to maintaining an open, community-driven approach to Mukurtu's continued development. Our first priority is to help build a platform that fosters relationships of respect and trust"; see http://mukurtu.org/about/.

13 William C. Wicken, The Colonization of Mi'kmaw Memory and History 1794-1928: The King V. Gabriel Sylliboy (Toronto: University of Toronto Press, 2012). 
these continuities, we can see the deep connection Mi'kmaq have maintained to the land since time immemorial. ${ }^{14}$

The archival record is rich with statements making clear this lasting connection between people and place. In the early 18th century, for example, Mi'kmaq captured New England fishing vessels at Canso and told the fishers that the lands were theirs. ${ }^{15}$ Similarly, in 1720 , Mi'kmaq advised the British that

if we would go to England for to live there, what would we be told but to leave, and we by the same reason, do not want the English to live in our lands, that we hold only of God and that we dispute to all men who want to live here without our consent. ${ }^{16}$

That same year Mi'kmaw diplomats told the French governor at Louisbourg "que nous sommes sur cette Terre que tu foule aux pieds et sur laquelle tu marche, avant mesme que ses arbres que tu Voyes n'eussent commence a en Sortir, Elle est a nous Et Rien ne pourra jamais nous l'ôter n'y nous la faire abandonnés. ${ }^{{ }^{17}}$ A Spanish captain taken off Louisbourg by the English claimed that the Mi'kmaq were "not absolutely subject to the king of France." Mi'kmaq neither altered their way of life nor submitted to French laws. ${ }^{18}$

Even after the Treaty of Utrecht, the Treaty of Paris, and the arrival of Loyalists during the late 18th century as well as Confederation and the Indian Act during the mid-to-late 19th century, the Mi'kmaq continued to select their own leaders, they remembered their treaties, and they continued to assert their sovereignty over their lands and waters. In 1783, for example, Angus Macdonald was given a grant of land at Merigomish. Shortly thereafter he left, went to the

14 Thomas Peace, "Immigration and Sovereignty: Lessons from the Distant Past," Journal of the Royal Nova Scotia Historical Society 19 (2016): 56; Jacob Remes, "Mi'kmaq in the Halifax Explosion of 1917," Ethnohistory 61, no. 3 (Summer 2014): 445-66.

15 David Jeffries and Charles Shepreve to Captain Robert Meares, 6 July 1715, in "America and West Indies: August 1715, 1-13," in Calendar of State Papers Colonial, America and West Indies: Volume 28, 1714-1715, ed. Cecil Headlam (London: His Majesty's Stationery Office, 1928), 254-68, 568.

16 "Lettres des Sauvages à Monsieur le Ceneral Philipps, aux Mines, le 2 octobre, 1720," Collection de manuscrits contenant Lettres, Mémoires et autres documents historiques relatifs à la Nouvelle-France recueillis aux Archives de la Province de Québec ou copiées à l'étranger, vol.3 (Québec: Imprimerie Coté, 1884), 46-7.

17 "Discours des Sauvages de l'Acadie au gouverneur de l'île Royale" and "Réponses que Monsieur de Saint-Ovide leur a faites," 1720, C11A, vol. 122, ff. 84-85v, Library and Archives Canada (LAC), Ottawa.

18 C.W. Vernon, Cape Breton Canada at the Beginning of the Twentieth Century: A Treatise of Natural Resources and Development, Nation Building Series (Toronto: Nation Publishing, 1903), 94. 
Miramichi, then to PEI, and then returned to Nova Scotia in the Arisaig area. Here, according to Rankin's history of Antigonish county, "he took up 500 acres of land, but owing to the hostility of the Indians, he left the place and returned to Merigomish." ${ }^{19}$ But Mi'kmaq in Merigomish also disputed the presence of incomers on their lands. The licences of occupation granted Mi'kmaq in the 178 os were in part a response to demands from Mi'kmaq for security in their lands and in part a way for the Crown to assuage the Mi'kmaq, who were increasingly frustrated at finding their fishing stations and other harvesting areas overrun by the burgeoning non-Mi'kmaw population. ${ }^{20}$

About 1820 , at the same time the first reserves in Nova Scotia were created, Mi'kmaq still conducted their own external relations. Isabel Googoo Morris of We'koqma'q told of San Sosef and six other Mi'kmaw men who travelled to Kahnawá:ke to make peace with the Gwedich (Mohawk) - their traditional enemies. ${ }^{21}$ In the mid-19th century, one visitor to Cape Breton wrote "It is a fact" that Cape Breton Mi'kmaq continue to consider that they are the "rightful owners" of Unama'ki and live on "friendly terms with the whites because [they were] obliged to do so."22

In 1866, in the shadow of the looming creation of Canada, the Mi'kmaq, concerned about their nation-to-nation relationship with the Crown, deputized two of their best English speakers to go to London to present Mi'kmaw concerns to the Queen Victoria. ${ }^{23}$ Their visit built upon at least one earlier in the 1820 s by Mi'kmaw diplomat Andrew Meuse. ${ }^{24}$

Similarly, in 1883, the Mi'kmaq met at Indian Brook in Hants County, Nova Scotia,

19 Duncan J. Rankin, A History of the County of Antigonish, Nova Scotia (Toronto: Macmillan, 1929), 12.

20 See, for example, George Henry Monk, Superintendent of Indian Affairs, Letter Book, pp. 1028, 1033-5, MG 23 G11-19, Monk Papers, vol. 3, (4) George Henry Monk 1748-1823, Letter Book, Indian Affairs, 1783-1797, Nova Scotia Archives; L.F.S. Upton, Micmacs and Colonists IndianWhite Relations in the Maritimes 1713-1867 (Vancouver: UBC Press, 1979), 82-3.

21 Elsie Clews Parsons, "Micmac Folklore," Journal of American Folklore 38, no. 147 (January-March, 1925): 93.

22 S.G.W. Benjamin, The Cruise of the Alice May in the Gulf of St. Lawrence and Adjacent Waters (New York: D. Appelton \& Co., 1885), 118.

23 J.C. Cope, "A Short History of the Mic Mac Indians in Halifax Co. Nova Scotia Since Confederation," 9 February 1926, in Harry Piers Ethnology Papers, Mi'kmaw Ethnology, vol. III, ed., trans. and annot. Ruth Holmes Whitehead (Halifax: Nova Scotia Museum, 2002), 158.

24 L.F.S. Upton, "Andrew Meuse," DCB Online, http://www.biographi.ca/en/bio/meuse_andrew_ james_7E.html. 
to frame a code of criminal laws respecting crimes committed by the Indians, and to appoint representatives of their body to meet with the Minister of Justice at Ottawa with a view of having said laws passed at the coming meeting of the Dominion Parliament. They claim that the present criminal laws of the Dominion do not apply to them .... They wish to have the laws so framed that they will have the sole control of judges, lawyers, etc. ${ }^{25}$

Such assertions continued throughout the 2oth century. During the aftermath of the White Paper, while Indigenous activism blazed across Canada post-1969, the Mi'kmaq of Nova Scotia forwarded their first title and rights claim to the provincial government; they argued, in part, that the "actions of the colonial powers in entering into treaties with Indians were an acknowledgement of sovereignty and a recognition of Indian rights to the land." The Crown was put on notice that Mi'kmaq would hunt, fish, and trap on their reserve land and unoccupied Crown land without "molestation and hindrance" and that rather than applying for, and carrying, provincial licences the Mi'kmaq would instead hold Union of Nova Scotia Indians "Status Cards." ${ }^{26}$

What is clear from this brief discussion is the continued nature of Mi'kmaw declarations of sovereignty. From time immemorial until the present, Mi'kmaw diplomats and activists have made their claim and deep abiding relationship to Mi'kma'ki clear. It has been the institutional nature of the archive, and the settler focus of many historians, that have obscured this past. The internet age and the digitization of historical resources provides an opportunity to work against these challenges and better represent to all citizens of Atlantic Canada this important and foundational history.

Our vision for the Mi'kmaq Sovereignty Database project is to provide a springboard to develop a website that is owned and directed by the Mi'kmaq - a website that will permit all Mi'kmaq as well as non-Mi'kmaq scholars, students, and the public to see the words of the Mi'kmaq that demonstrate that the Mi'kmaq never forgot they were, and are, self-governing. The database must be accessible not only to scholars but also to Mi'kmaw individuals and others. It must be easily navigable. To fulfill this ambitious mandate - especially on

25 Bridgetown Weekly Monitor, 7 February 1883.

26 Nova Scotia Micmac Aboriginal Rights Position Paper, presented to the government of Canada by the Union of Nova Scotia Indians, Micmac News 5, no. 12A (December 1976), 44. 
a non-existent budget - we hope volunteers from the academy and others will help us populate the database with materials garnered in their research.

Over the past several years, we have received excellent suggestions from colleagues. One Mi'kmaw individual with a background in primary and secondary education, for instance, suggested establishing different sections or rooms on the database aimed at different audiences, where teachers could access grade-appropriate materials and teaching plans. Another suggestion was to open a space on the database where undergraduate and graduate students could upload papers and research notes, something that would also provide them with an opportunity to publish. And a senior Indigenous historian thought we should "dream big" and think about expanding the database over time to provide a central forum for all primary materials relating to the Mi'kmaq - and the Wolastoqiyik and Peskotomuhkati. We continue to tinker with the prototype.

On one point we are firm: this must be a Mi'kmaw-governed initiative. As two non-Mi'kmaw historians, we think that this resource is necessary if we are to move past the colonial oppressions that defined our region's past; to do it right we need to move slowly and ensure Mi'kmaw governance and control. As such, we have had initial meetings with Mi'kmaw scholars and community members who have agreed to act as a preliminary Board of Directors.

The slow pace of progress in getting the database up and running is the result of a number of factors. First we had to obtain acceptance and support from the Mi'kmaw leadership, and the Assembly of Nova Scotia Mi'kmaq Chiefs quickly signed on to the project. We anticipate that this project will soon also garner support from the Mi'kmaw leadership in the Gaspé, New Brunswick, and PEI, which will enable us to obtain data from other regions of Mi'kma'ki.

Secondly, the database project is unfunded and so time must be carved out from busy schedules. The members of our preliminary volunteer Board of Directors have numerous demands on them, and we have to be mindful of their commitments to their institutions and communities. While we hope in the future to hire a graduate student to do the actual work of uploading documents, and funding could be available from sources such as SSHRC, many members of the Board of Directors have other applications for projects before funding agencies and cannot sign on as a principal for an application for funding for this project. 
We may seem to be moving at the pace of a sedate mikjikj (turtle), but we want to do this right. In keeping with the spirit of the TRC Calls to Action on education, we believe that this project, driven and directed by Mi'kmaq in collaboration with scholars both inside and outside of the academy, can help educate Mi'kmaq and non-Mi'kmaw about Mi'kmaw determination through many generations to ensure their nation survives and thrives.

The collaborative approach between a community and the academy, modeled by NNP and GRASAC, and envisioned in our nascent project, promotes mutual understanding. Academics are often charged with being too insular and remote. Scholars, particularly historians, can be unaware of contemporary concerns and issues within the communities or fields they study. Working together can foster a deeper understanding in community members of the past and a better appreciation by academics of present issues faced by communities.

We also believe that this project can assist in decolonizing the academy. The earlier archival activists - Atkins, Macmechan, Ganong, and Webster - applied a non-Indigenous approach to the significance the materials they included in their compilations and anthologies. The vision for the Sovereignty Database, like that of the Native Northeast Portal, is to remove such filters, consciously or unconsciously applied, from the collection and dissemination of primary (and secondary) documents. Digitizing and uploading primary materials and thus allowing the documents to speak for themselves, and to associate diverse interpretations of them, allows Mi'kmaq through time to better speak for themselves.

THOMAS PEACE and GILLIAN ALLEN

THOMAS PEACE est professeur adjoint d'histoire au Collège universitaire Huron. Ses recherches portent sur la colonisation de peuplement et l'éducation dans le Nord-Est au $18^{\mathrm{e}}$ et $19^{\mathrm{e}}$ siècles.

THOMAS PEACE is an assistant professor of history at Huron University College. His research focuses on settler colonialism and education in the 18th- and 19th-century northeast.

GILLIAN ALLEN est agente principale de recherche pour le Kwilm'kw Maw-klusuaqn Negotiation Office. Elle travaille depuis plus de 25 ans pour la nation mi'kmaq dans les domaines de la recherche, de la négociation et du règlement de litiges en matière de titres autochtones, de droits autochtones et de droits issus des traités.

GILLIAN ALLEN is the senior research officer for the Kwilm'kw Maw-klusuaqn Negotiation Office. She has worked for more than 25 years for the Mi'kmaw Nation in the field of Aboriginal title, Aboriginal rights, and treaty rights research, negotiation, and litigation. 